\title{
ALUMINIUM: FOOD-RELATED HEALTH RISK ASSESSMENT OF THE CONSUMERS
}

\author{
O.V. Bagryantseva ${ }^{1}$, G.N. Shatrov ${ }^{1}$, S.A. Khotimchenko ${ }^{1}$, \\ V.V. Bessonov ${ }^{1}$, O.V. Arnautov ${ }^{2}$ \\ ${ }^{1}$ Federal State Budgetary Scientific Institution Scientific Research Institute of Nutrition Address, \\ Ustyinsky pr., 2/14, Moscow, 109240, Russian Federation \\ ${ }^{2}$ Sanitary, Phytosanitary and Veterinary Measures Department of the Eurasian Economic Commission, \\ Smolensky blv, house 3/5, build. 1, Moscow, 119121, Russian Federation
}

Aluminum is the most abundant metal in the lithosphere, constituting $8 \%$ of the earth's crust. Aluminum enters the food from the various objects of environment such as water, food contact materials (packaging materials, cooking vessels), aluminum-containing food additives. In raw food products the content of aluminum is less than $5.7 \mathrm{mg} / \mathrm{kg}$ of the product.

Normally, aluminum is not practically found in a human body. However, within the last decade various toxic effects of aluminum on human body have been revealed, and they are able to cause the risk of various diseases.

The analysis of the available data has demonstrated that the excessive entry of aluminum in human body with food items is associated first of all with the content of aluminum-containing food additives, as well as with the use of materials and products made of aluminum and its alloys intended for contact with food.

High level of aluminum consumption has been also detected among children of all ages. At the same time, today, the provisional tolerable weekly intake (PTWI) of aluminum for children is not established.

To reduce negative effect of aluminum on human body it is necessary to:

- exclude from the list of Annex 2 of the Technical Regulations of the Customs Union "Requirements for Food Additives, Flavorings and Technological Aids" (TR TS 029/2012) the following food additives - potassium aluminum silicate (E555), bentonite (E558), sodium aluminum silicate (E554), potassium aluminum silicate (E555), calcium aluminum silicate (E556), aluminum silicate (kaolin) (E559);

- to develop requirements for the aluminum content in food products intended for children nutrition;

- to obtain data on aluminum content in food items sold on the domestic market and to assess health risks to consumers.

Key words: aluminum, toxicity, risk assessment, food additives, food items, food contact materials and products.

Aluminium is the most widely spread metal in lithosphere accounting for $8 \%$ of Earth's crust. Aluminium gets into food from various environmental objects such as water, food-contacting materials (packages, cooking battery and cooking accessories), and aluminium-bearing food additives. Aluminium content in crude food stuffs amounts to less than 5$7 \mathrm{mgr} / \mathrm{kg}$ of a product $[32,20]$.

We should point out that as per physiological standard aluminium is practically absent in a human body. However, over the last decade scientists have detected various toxic effects exerted by aluminium on a human body; such effects can cause risk of various diseases evolvement.

Our goal is to assess health risks caused by aluminium as well as justify measures aimed at reducing levels of aluminium intake with food products.

\section{Aluminium bioavailability and tox- icity}

When getting into gastric acid medium aluminium compounds can dissolve and $\mathrm{Al}_{3}+$ free ions are disengaged. As $\mathrm{Al}_{3}+$ ions pass 
through duodenum with higher $\mathrm{pH}$ they are precipitated as insoluble aluminium hydroxide, a great amount of which leaves a body with excrements [4]. Researches carried out on rats have shown that only $0.01 \%$ to $0.3 \%$ of consumed aluminium compounds are absorbed in bowels. Rat dams tend to absorb more aluminium than rat bucks and this absorption increases when aluminium compounds are injected again [9]. Researches accomplished on volunteers have revealed the similar level of absorption as in rats. Absorption degree was $0.5 \%$ for aluminium citrate, $0.01 \%$ for aluminium hydroxide, and $0.1 \%$ for their combined injection [24]. Scientists also detected significant ability to accumulate aluminium in elderly people $[9,11]$.

Our research has shown that bioavailability of various aluminium compounds contained in water amounts to $0.3 \%$; in food stuffs to $0.1 \%$. If aluminium intake level is $15 \mathrm{mgr}$ per day 0.025 mgr leave a body with urine. And here only $5 \%$ of aluminium is accumulated in body tissues. About half of this amount is accumulated in bone tissue. Aluminium is also contained in skin, tissues of gastrointestinal tract's lower section, lymph nodes, adrenals, parathyroid, and most internals. Experiments on rats have proved that if aluminium gets into a body with food its accumulation is significantly greater in pancreas, liver, bones and kidneys, and it is lower in cerebrum, muscular tissue, heart and lungs. There are also some thoughts that aluminium can pass through placental barrier [11].

$90 \%$ of aluminium $\left(\mathrm{Al}_{3+}\right)$ in blood plasma is related to transferrin and about $10 \%$ to citrates. It is proved that Fe contain in a body reduces as aluminium concentration in tissues grows. $\mathrm{Ca}$ and $\mathrm{Mg}$ deficiency contributes to aluminium accumulation in bone and cerebrum tissues $[11,32]$.

Average lethal dose in experiments on different animals varied from some hundreds to $1000 \mathrm{mgr}$ per $1 \mathrm{~kg}$ of body weight (in terms of aluminium). According to various researches the lowest aluminium dose causing observable negative effects in rats amounts to 75-80 mgr per $1 \mathrm{~kg}$ of body weight per day [11].
Aluminium has negative influence on kidneys (it leads to hydronephrosis transformation, urinary ducts widening, urination difficulties and/or litho genesis). In accordance with latest in vitro experiments significant concentration of aluminium exerts genotoxic effects on bacterial cells chromosomes and homoiotherms cells. It has been fixed that injected big doses of some aluminium compounds can potentially have negative influence on dogs' reproductive system and be neurotoxic for mice and rats $[4,9,11]$.

Experiments in vitro carried out with the use of Salmonella typhimurium have not proved any possibility of mutagenic effect caused by aluminium [7]. Big doses of aluminium compounds injected via gastric tube have shown a possibility of embryotoxic effect evolvement in mice and rats as we observe lower fetus weight and lower newborn cubs' weight, as well as delay in bone tissue calcification in newborns $[4,11]$. Researches on rat dams getting aluminium chloride via gastric tube have revealed its fetotoxicity $[9,5,11]$.

Soluble aluminium compounds have shown their reproductive toxicity. They can cause histopathological changes in testicles and have negative influence on pregnancy length; they can contribute to greater fetus mortality, lower growth dynamics, arrested development and disorders in nervous system development. However it has been stated that aluminium toxicity when aluminium is introduced orally to a greater extent depends on a type of an aluminium compound and presence of organic compounds influencing its bioavailability in food [5].

A number of researches have shown that aluminium intake with drinking water can make for dementia evolvement and Alzheimer syndrome [9, 8, 34, 35]. Such effect can be explained by the fact that aluminium salts contribute to inflammatory cytokine activation in cerebrum [12].

Aluminium can cause allergic dermatitis [31]. However there have been no statements on allergenicity of aluminium when it gets into a body with food. 
We have detected reduction in relative liver and lungs weight, level of non-protein liver thiols, changes in CYP1A1 isoform activity of P450 liver cytochrome and glutathionereductase of erythrocytes, and increased level of diene conjugates of polyunsaturated fatty acids in blood plasma, among effects possibly related to the influence of aluminium oxide nanoparticles injected via gastric tube into growing Vistar rat bucks daily during 28 days, a daily dose being 1 or $100 \mathrm{mgr} / \mathrm{kg}$. The above stated changes in biochemical parameters were not significant in their absolute value and were within natural variations range for biological standard or they didn't show any certain dependency on an injected nanoparticles' dose. But at the same time we think that as such nanomaterial can be a significant pollutant contaminating environment and food products further researches of its possible toxicity should be carried out with injecting low doses (1 $\mathrm{mgr} / \mathrm{kg}$ and even lower) over a long period of time [3].

FAO/WHO Joint Expert Committee on Food Additives (JECFA) has repeatedly assessed aluminium safety when it gets into a body from all possible sources. According to these assessments in 1988 JECFA fixed provisional tolerable weekly intake (PTWI) for aluminium which amounted to $0-7 \mathrm{mgr}$ per $1 \mathrm{~kg}$ of body weight per one week. A new PTWI amounting to $0-1 \mathrm{mgr}$ per $1 \mathrm{~kg}$ of body weight per one week was fixed as new toxicological data were obtained in 2007 [5]. Reassessment of aluminium getting into a body from all possible sources accomplished in 2011 enabled JECFA to set a new level of a safe weekly intake (PTWI) amounting to $0-2.0 \mathrm{mgr}$ per $1 \mathrm{~kg}$ of body weight per one week (in terms of aluminium) [9]. Thus, fixed permissible level of aluminium intake for a man with average body weight of $60 \mathrm{~kg}$ amounts to $120 \mathrm{mgr}$ per one week. Such PTWI level cannot be used for children under 1 year as their metabolic functions and their kidneys' abilities to excrete foreign substances are not fully developed [8]. In 2011 European Food Safety Agency defined tolerable weekly intake (TWI) for aluminium as being equal to 1 mgr per $1 \mathrm{~kg}$ of body weight [4].

\section{Assessment of aluminium intake with food stuffs}

In accordance with researches carries out in European Union in 2008 aluminium intake with food amounts to 1.6 - 13 mgr of aluminium a day. Such amount is equal to 0.2$1.5 \mathrm{mgr}$ per $1 \mathrm{~kg}$ of body weight for an adult weighing $60 \mathrm{~kg}$. Difference in aluminium intake depends on place of living, soil composition, individual food habits, as well as content of aluminium-bearing food additives in food stuffs. A body weight plays a very significant role in the matter. Aluminium intake with water amounts to less than $0.4 \mathrm{mgr}$ a day.

Researches accomplished in West Germany, France, Great Britain, Ireland and Spain, showed that a great deal of crude food stuffs contained $5-7 \mathrm{mgr} / \mathrm{kg}$ of aluminium [8, $9,15,16,32]$. Higher aluminium concentrations (from 5 to $10 \mathrm{mgr}-\mathrm{kg}$ ) were detected in bread, confectionary and bakery products, some vegetables (spinach, radish, lettuce, and corn salad), mushrooms, candied fruit, dairy compounds, boiled sausages, by-products, and seafood. The biggest aluminium content was in leaf and packed tea, herbs, cocoa and its products, and spices [4].

It is well known that aluminium gets into food products from various environmental objects as well as due to aluminium-bearing food ingredients, for example, food additives; it can also get into food in the process of food production, packaging and storage as a result of contacts with various aluminium-bearing materials and equipment $[6,9,15,16,32]$.

The greatest aluminium intake for $97.5 \%$ of consumers amounted to 0.4 mgr per $1 \mathrm{~kg}$ of body weight in France and $0.94 \mathrm{mgr}$ per $1 \mathrm{~kg}$ of body weight in Great Britain. Elderly people had greatest aluminium intake with food in Great Britain where it amounted to 1.14 mgr per $1 \mathrm{~kg}$ of body weight per week $[4,5]$.

As it was estimated by World Health Organization, average aluminium intake into a 
human body from all possible sources (water, food stuffs, package, and air) is from 11 to 136 mg per 1 person per week. In European countries this parameter is from 11 to 91 mgr per 1 person per week.

In accordance with EFSA assessment, intake of five aluminium-bearing food additives (aluminium-ammonium sulphate (E523); acid $\mathrm{Na}$ aluminium phosphate (E541); Na alumosilicate (E554); Ca alumosilicate (E556); alumosilicate (kaolin) 9E559)) for various age groups (younger children, children, teens, adults, elderly people) is on average from 2.3 to $7.9 \mathrm{mgr}$ per $1 \mathrm{~kg}$ of body weight per week and from 7.4 to $145.9 \mathrm{mgr}$ per $1 \mathrm{~kg}$ of body weight per week for $95 \%$ of population depending on a scheme taken into account. If we consider the second scheme which envisages greater intake of food stuffs with aluminiumbearing food additives in them we get the following amounts: average intake is equal to 18.6-156.2 mgr per $1 \mathrm{~kg}$ of body weight per week, intake for $65 \%$ of population sample is equal to 5.3-286.8 mgr per $1 \mathrm{~kg}$ of body weight. So it was proved that aluminium intake in food stuffs containing aluminiumbearing food additives in various age groups was significantly higher than safe intake from all sources (TWI $=1 \mathrm{mgr}$ per $1 \mathrm{~kg}$ of body weight) set by EFSA, as well as than aluminium provisional tolerable weekly intake (PTWI $=0-2.0 \mathrm{mgr}$ per $1 \mathrm{~kg}$ of body weight) set by JECFA [16].

The results obtained by other authors prove the fact that children, as a rule, consume greater amount of aluminium in terms of body weight than adults, although such data differ slightly from those obtained by EFSA. In accordance to these data possible aluminium intake in $97.5 \%$ cases for children in France amounted to $0.7 \mathrm{mgr}$ per $1 \mathrm{~kg}$ of body weight for children aged 3-15 years. For pre-school children (aged 1.5-4.5) the figure was $2.3 \mathrm{mgr}$ per $1 \mathrm{~kg}$ of body weight per week. In 1988 in Great Britain aluminium intake by children aged 4-18 amounted to $1.7 \mathrm{mgr}$ per $1 \mathrm{~kg}$ of body weight per week. In West Germany $10 \%$ of children aged 5-8 consumed aluminium with food in amounts bigger than 0.38 mgr per
$1 \mathrm{~kg}$ of body weight per week. Potential aluminium intake with food by children aged 0-3, 4-6, 7-9 and 10-12 months was $0.1,0.2,0.43$ and $0.78 \mathrm{mgr}$ per $1 \mathrm{~kg}$ of body weight per week correspondingly $[4,5]$. Researches carried out in China showed that average aluminium intake for children in Shenzhen amounted to $3.272 \mathrm{mgr}$ per $1 \mathrm{~kg}$ of body weight per week that was higher than PTWI $=2$ mgr per $1 \mathrm{~kg}$ of body weight per week set for adults [6].

Researches accomplished in 2010 revealed that aluminium intake level with food products made for children aged 6 months and older was significantly high even when such products were consumed in recommended quantities. As per given data aluminium intake with different products made for nutrition of children aged 0-12 months varied from 224 $\mathrm{mgr} / \mathrm{kg}$ a day to $592 \mathrm{mgr} / \mathrm{kg}$ a day. The data were obtained in terms of maximum recommended intake for those products [30].

Researches in Spain showed that aluminium content in reduced milk-based baby food stuffs was 0.24-0.69 mgr/l, and 0.93 $\mathrm{mgr} / \mathrm{l}$ in soy-based ones [23]. The obtained data were used as a ground to carry out an additional assessment of aluminium intake with those foodstuffs and the figure was 0.2-0.6 $\mathrm{mgr} / \mathrm{kg}$ per week for children aged 3 months weighing 6.1 when milk-based products were used; it was equal to $0.75 \mathrm{mgr} / \mathrm{kg}$ per week in case of soy-based products. In cases of significant intakes those values were 0.3-0.9 mgr per $1 \mathrm{~kg}$ of body weight per week and $1.1 \mathrm{mgr}$ per $1 \mathrm{~kg}$ of body weight correspondingly [4]. The obtained data revealing higher aluminium content in children's food products (dairy products, biscuits, dry grain mixes, desserts, fish, fruit sauce, meat, macaroni, rusks, and vegetables) were confirmed by a number of researches $[4,8,29]$.

We should note that aluminium-bearing food additives are not included in the list of food additives which are allowed for use in food products made for children in accordance with Technical Regulations of Customs Union "Safety of food additives, flavorings and processing aids" (TR CU 029/2012) [2], "General standard for food additives" Alimentarius Co- 
dex Stan №192-1995 [17], EU Regulations No.1333/2008 concerning use of food additives. Besides, EU Regulations No.1333/2008 prohibit use of aluminium-bearing food additives in production of ingredients for children's nutrition. Consequently, aluminium gets into children's nutrition from milk or any other animal and vegetable raw materials; it can get into such materials with food additives and with aluminium-bearing forages as well as migrate from materials contacting with food products. This circumstance makes it necessary to work out special requirements for aluminium content in food products used for children's nutrition.

Level of aluminium migration form materials contacting with food

Under normal conditions aluminium entry into food from materials contacting with food products is insignificant as aluminium and its alloys are corrosion-proof. On open air aluminium due to its reaction with air oxygen gets covered with thin aluminium oxide film $\left(\mathrm{AL}_{2} \mathrm{O}_{3}\right)$ very rapidly. This film does not have any smell and it cannot be washed off [10]. In neutral environment aluminium oxide film is practically insoluble. However, when food $\mathrm{pH}$ is lower than 4.5 and higher than 8.5 its solubility increases substantially [19], especially if there are damages on the surface of aluminium oxide layer. Use of aluminium cooking batteries in the process of food cooking and storage contributes to higher aluminium content in certain types of food. So, aluminium can get into food from materials contacting with it. High content of sodium chloride in food stuffs (higher than $3.5 \% \mathrm{NaCl}$ ) also makes for entry of aluminium ions into food [27].

When water boils in an aluminium pan for 10-15 minutes, aluminium content in it is equal to approximately $1.5 \mathrm{mgr} / \mathrm{l}$. This value can differ depending on water acidity and aluminium alloy composition [11, 19, 27]. Only one experiment report stated aluminium migration level being $5 \mathrm{mgr} / 1$ [27].

Temperature and storage period also have great influence on aluminium migration from materials contacting with food. Thus, when $3 \%$ acetic acid was used as a model environment aluminium migration level during 24 hours was approximately 10 times higher at 40 degrees than at 5 degrees. When aluminium foil was used aluminium migration level was less than $0.05 \mathrm{mgr} / \mathrm{dm}^{2}$ at 5 degrees, but it was $96 \mathrm{mgr} / \mathrm{dm}^{2}$ at 40 degrees [18]. When meat was baked in aluminium foil aluminium content in a ready product was 5 times higher (up to $17.2 \mathrm{mgr}$ of aluminium per $1 \mathrm{~kg}$ of a product) [33].

A combined effect was detected when food was heated and treated with $\mathrm{pH}$ in the process of cooking. Thus, when fish was cooked without salt and grape vinegar aluminium content in a food product grew 4 times and reached about 0.4 mgr of aluminium per 1 $\mathrm{kg}$ of a product. But if salt and vinegar was added to fish aluminium content in a food product became 68 times higher and reached approximately $5 \mathrm{mgr}$ of aluminium per $1 \mathrm{~kg}$ of a product [25]. Some later experiments confirmed possibility of aluminium migration from aluminium foil in the process of cooking meat. So it was proposed to monitor aluminium content in baked meat [21].

Consequently, speed of aluminium migration from materials contacting with food depends on several factors, such as length of contact, heating temperature, food chemical composition (its $\mathrm{pH}$, organic acids presence, salt and other ions presence). Therefore we do not recommend using aluminium-based packages for storage of food stuffs which contain a big quantity of salt or acid (for example, pickles marinated vegetables, apple sauce, rhubarb, tomato sauce, and vinegar). It is proved that aluminium migration level greatly depends on geometry of a material or object and can reach $60 \mathrm{mgr} / \mathrm{kg}$ or $10 \mathrm{mgr} / \mathrm{dm}^{2}[19,27]$.

\section{Measures we suggest to achieve low- ering aluminium intake with food}

The obtained data on aluminiumbearing food additives toxicity and levels of aluminium intake with food stuffs were used as a ground to exclude $\mathrm{K}$ alumosilicate E555 
and bentonite E558 form the list of food additives given in "General standard on food additives" (Codex Stan 192-1995). However the possibility of exceeding maximum allowable aluminium intake when food additives are used still exists. So the Russian Federation made a suggestion to revise the list of aluminium-bearing food additives allowed for use in food industry at the $46^{\text {th }}$ session of Codex Alimentarius Committee on food additives CCFA46 (which took place in Hong Kong on March 17-21, 2014). CCFA46 agreed to that suggestion [28].

In accordance with EU legislation it was decided to exclude the following food additives form the list of those allowed for use in food industry: Sodium alumosilicate E554, Potassium Alumosilicate E555, Calcium Alumosilicate E556, Bentonite E558, Alumosilicate Kaolin E559 [14, 26].

So, according to requirements of "General standard on food additives" (Codex Stan 1992-1995) (with alterations of 2014) [17], as well as requirements of EU Regulations No.1333/2008 (with alterations of 2015) [26] it is suggested to exclude the following aluminium-bearing food additives from the list of those allowed for use in food industry given in Technical Regulations of Customs Union "Safety of food additives, flavorings and processing aids" (TR CU 029/2012): Sodium alumosilicate E554, Potassium Alumosilicate E555, Calcium Alumosilicate E556, Bentonite E558, Alumosilicate Kaolin E559.

In spite of all obtained data on aluminium toxicity European Food Safety Agency proposed to set maximum allowable level of aluminium migration from materials contacting with food at $5 \mathrm{mgr} / \mathrm{l}$ because as per published information contemporary production cannot provide migration level for aluminium and its alloys lower than $5 \mathrm{mgr} / \mathrm{kg}$ (l) of environment. Possibility to solve the problem of migration level from materials contacting with food will be considered by the European Union during 3 years [22].

We should also point out that according to TR CU 005/2011 requirements "On package safety" maximum allowable level of aluminium migration into model environment should not exceed $0.5 \mathrm{mgr} / 1$ [1]. However, in accordance with TR CU 005/2011 requirements "On package safety" model environments containing acids (lactic and acetic acids), sodium chloride, and ethanol, are used to define the level of substances migration from contacting materials [1]. So, when we use above mentioned model environments in accordance with Technical Regulations we cannot obtain valid data on aluminium migration from materials contacting with food because all employed types of environments are sufficiently aggressive concerning aluminium and its alloys. Therefore, in order to get adequate results of aluminium migration level analysis it is necessary to use other model environments. Thus, according to EU regulations No.10/2011 [13] a choice of a model environment depends on a type of a food product which is supposed to contact with an aluminium-bearing material or accessories.

\section{Conclusion}

So, we recommend the following measures aimed at lowering levels of aluminium intake with food:

- to exclude such food additives as Sodium alumosilicate E554, Potassium Alumosilicate E555, Calcium Alumosilicate E556, Bentonite E558, Alumosilicate Kaolin E559 from the list presented in Appendix 2, Technical Regulations of Customs Union "Safety of food additives, flavorings and processing aids" (TR CU 029/2012);

- to work out requirements concerning aluminium content in food stuffs used for children's nutrition;

- to obtain data on aluminium content in food stuffs sold on internal food market and assess health risk for

\section{References}


1. Shumakova A.A., Tananova O.N., Arianova E.A., Mal'cev G.Ju., Trushina Je.N., Mustafina O.K., Guseva G.V., Trusov N.V., Soto S.H., Sharanova N.Je., Selifinov A.V., Gmoshinskij I.V., Hotimchenko S.A. Izuchenie vozdejstvija nanochastic oksida aljuminija, vvodimyh v zheludochno-kishechnyj trakt [Investigation of oxide aluminum nanoflake administered into rat's gastrointestinal tract]. Voprosy Pitaniia, Vol. 81, no. 6, 2012, pp. 54-60. (in Russian).

2. O bezopasnosti upakovki: Tehnicheskij reglament tamozhennogo sojuza [Technical Regulations of the Customs Union "On the safety of the package" TR CU 005/2011]. Available at: http: //www.tsouz.ru/KTS/ KTS30/Documents/P_769_1.pdf (20.10.2015). (in Russian).

3. Trebovanija bezopasnosti pishhevyh dobavok, aromatizatorov i tehnologicheskih vspomogatel'nyh sredstv: Tehnicheskij reglament tamozhennogo sojuza TR CU 029/2012TP TC 029/2012 [Technical Regulations of the Customs Union "Safety of food additives, flavorings and processing aids" TR CU 029/2012TP TC 029/2012]. Available at: http: //www.aleksandrovka56.ru/assets/files/SelHoz/Reg1/Reglament 4.pdf (20.10.2015). (in Russian).

4. Aluminium (from all sources, including food additives). Evaluation of certain food additives and contaminants: sixty-seventh report of the Joint FAO. WHO Expert Committee on Food Additives. WHO Technical Report, 2007, Series 940, pp. 33-45.

5. Benford D.J., Thatcher N., Mason D. [et al.]. Aluminium from all sources, including food additives and contaminants (addendum). First draft. Safety evaluation of certain food additives and contaminants. WHO Food additives, 2007, Series 58, pp. 119-209.

6. Jon I Mujika, Elixabete Rezabal, Jose M Mercero [et al.]. Aluminium in Biological Environments: A Computational Approach. Computational and structural biotechnology journal, 2014, Vol. 9, Issue: 15, pp. 1-13.

7. Aluminium in food. Risk Assessment. Studies Report No. 35.Chemical Hazard Evaluation. Centre for Food Safety Food and Environmental Hygiene Department. The Government of the Hong Kong Special Administrative Region, 2009, 45 p.

8. Gramiccioni L.G., Ingrao M. R., Milana P. [et al.]. Aluminium levels in Italian diets and in selected foods from aluminium utensils. Food Add Contam, 1996, Vol. 13 (7), pp. 767-774.

9. Aluminium production. IARC monographs on the evaluation of the carcinogenic risk to humans. Supplement 7, 1987, pp. 89-91.

10. Aluminium-containing food additives (addendum). Safety evaluation of certain food additives and contaminants. Prepared by the Seventy-fourth meeting of the Joint FAO. WHO Expert Committee on Food Additives (JECFA). WHO food additives, 2012, Series 65, pp. 3-87.

11. Aluminium-containing food additives. Evaluation of certain food additives and contaminants. WHO Technical Report Series 966, 2011, pp. 7-14.

12. Virginie Rondeau, Hélène Jacqmin-Gadda, Daniel Commenges [et al.]. Aluminum and silica in drinking water and the risk of Alzheimer's disease or cognitive decline: findings from 15-year follow-up of the PAQUID cohort. Am J Epidemiol. Feb, 2009, Vol. 169 (4), pp. 489-496.

13. Robert L. Poole, Kevin P. Pieroni, Shabnam Gaskari [et al.]. Aluminum Exposure in Neonatal Patients Using the Least Contaminated Parenteral Nutrition Solution Products. Nutrients, 2012, Vol. 4, pp. 1566-1574.

14. Beliles R.P. The metals. In: Patty's Industrial Hygiene and Toxicology. Fourth edition, 1994, Vol. 2, part C, pp. 22-46.

15. Bondy S.C. The neurotoxicity of environmental aluminum is still an issue. Neurotoxicology, 2010 Sep, Vol. 31 (5), pp. 575-81.

16. Commission regulation (EU) No 10/2011 of 14 January 2011 on plastic materials and articles intended to come into contact with food // Official Journal of the European Union, 201, L 12, pp. 1-89.

17. Commission regulation (EU) No 380/2012 of 3 May 2012 amending Annex II to Regulation (EC) No 1333/2008 of the European Parliament and of the Council as regards the conditions of use and the use levels for aluminium-containing food additives.Official Journal of the European Union, 2012, L 119, pp. 14-38.

18. Dietary exposure to aluminium-containing food additives. Technical report. Supporting Publications, 2013, EN-411, 17 p.

19. Siemund I, Zimerson E, Hindsen M, Bruze M. Establishing aluminium contact allergy. Contact Dermat, 2012, Vol. 67 (3), pp. 162-70.

20. General standard food additives. CODEX STAN 192-1995. Available at: http: //www.maff.go.jp/j/shokusan/seizo/pdf/gsfa2013-01.pdf (16.06.2015).

21. Guidelines on metals and alloys used as food contact materials and alloys. Technical document. Council of Europe (13.02.2002). Available at: http: //www.coe.int/t/e/social_cohesion/soc-sp/public health/food_contact/TECH \% 20DOC \% 20GUIDELINES \% 20METALS \% 20AND \% 20ALLOYS.pdf (18.09.2015).

22. Daniel Krewski, Robert A Yokel, Evert Nieboer et al. Human health risk assessment for aluminum, aluminum oxide, and aluminum hydroxide. J Toxicol Environ Health B Crit Rev, 2007, vol. 10 (Suppl 1), pp. 1-269.

23. Layla A. Al Juhaiman Estimating Aluminum Leaching into Meat Baked with Aluminum Foil Using Gravimetric and UV-Vis Spectrophotometric Method. Food and Nutrition Sciences, 2015, vol. 6, pp. 538-545. 
24. Metals and alloys used in food contact materials and articles: A practical guide for manufacturers and regulators. Quality of Medicines \& Health Care of the Council of Europe (EDQM), 2013, 217 p.

25. Navarro-Blasco I., Alvarez-Galindo J.I. Aluminum content of Spanish infant formula. Food Addit. Contam, 2003, vol. 20, pp. 470-481.

26. Ranau R., Oehlensclager J., Steinhart H. Aluminum Levels of Fish Fillet Baked and Grilled in Aluminum Foil. Food Chemistry, 2001, Vol. 73, pp. 1-6.

27. Regulation (EC) No 1333/2008 of the European Parliament and of the Council of 16 December 2008 on food additives (Text with EEA relevance) Available at: https: //www.fsai.ie/uploadedFiles/Consol_Reg1333_2008.pdf (16.06.2015).

28. Virginie Rondeau, Daniel Commenges, Hélène Jacqmin-Gadda [et al.]. Relation between aluminum concentrations in drinking water and Alzheimer's disease: an 8-year follow-up study. Am J Epidemiol. Jul, 2000, vol. $152(1)$, pp. 59-66.

29. Report of ESCO WG on non-plastic Food Contact Materials. External scientific report. Supporting Publications, 2012: EN-139, 63 p.

30. Report of the forty-sixth session of the codex committee on food additives, (Hong Kong, China 17-21 March 2014). Food and Agriculture Organization of the United Nations. Available at: https: //www.google.com/url?q=http: //www.fao.org/input/download/report/903/REP14_FAe.pdf\&sa=U\&ved=0ahUKEwjQ2Nbdo6bLAhWia5oKHW95AE 4QFggFMAA\&client=internal-uds-cse\&usg=AFQjCNE31mhFACMH3xdwFjR5YV3UdM8mZA (21.09.2015).

31. Aguilar F., Autrup H., Barlow S. [et al.]. Safety of aluminium from dietary intake. Scientific Opinion of the Panel on Food Additives, Flavourings, Processing Aids and Food Contact Materials (AFC). The EFSA Journal, 2008, vol. 754, pp. 1-34.

32. Shelle-Ann M Burrell, Christopher Exley There is (still) too much aluminium in infant formulas. Burrell and Exley BMC Pediatrics, 2010, no. 10, pp. 63-67.

33. Statement of EFSA. On the Evaluation of a new study related to the bioavailability of aluminium in food. EFSA Journal, 2011, vol. 9, no. 5, pp. 2157-2173.

34. Priest N.D., Talbot R.J., Austin J.G. [et al.]. The bioavailability of 26 Al-labelled aluminium citrate and aluminium hydroxide in volunteers. BioMetals, 1996, vol. 9, pp. 221-228.

35. Turhan S. Aluminium Contents in Baked Meats Wrapped in Aluminum Foil. Meat Science, 2006, vol. 74, pp. 644-647. 